<症例報告 $>$

\title{
腹腔鏡下肝生検にて肝内異所性膵組織が発見された $\mathrm{B}$ 型慢性肝炎の 1 例
}

\begin{tabular}{|c|c|c|c|c|}
\hline 裕貴 & 尾形靖一郎 & 小池 & 淳樹 & 相田 \\
\hline 史朗 & 打越 敏之 ${ }^{1)}$ & 佐藤 & 明 & 鈴木 \\
\hline
\end{tabular}

\begin{abstract}
要 旨：症例は44歳男性. B 型慢性肝炎にて経過中, インターフェロン治療前評価として腹腔 鏡下肝生検が施行された。その生検肝組織の深部側の一部に偶然膵組織をみとめたが, その後 の画像検査にて肝内に膵組織を検出することはできなかった。B 型慢性肝炎の治療に直接的な 関係はなかったが, 発生学的に興味がもたれる比較的まれな肝内異所性膵組織をみた症例であ ると考えられた。
\end{abstract}

索引用語： 肝内異所性膵 $\mathrm{B}$ 型慢性肝炎 腹腔鏡下肝生検

\section{はじめに}

異所性膵は迷入萃，副膵と同義語として，解剖学的 に正常膵臓と連続性がなく，血管の支配も異なる膵組 織である. 発生頻度は約 1〜2\%といわれ，その発生 部位の大多数が上部消化管であるといわれている ${ }^{1,2)}$. 発生頻度の高い臓器は十二指腸や胃であるが，その頻 度については報告者により様々である ${ }^{1,2)}$.

今回, 腹腔鏡下肝生検にて偶然に肝内異所性膵組織 が発見された B 型慢性肝炎の 1 例を経験したので若干 の文献的考察を含めて報告する。

\section{症例}

症例：44歳, 男性.

既往歴：特記すべきことなし。

家族歴：母親は $\mathrm{HBV}$ キャリヤー.

現病歴：1978年に会社の検診で肝機能障害を指摘さ れ，近医にて精查後 $\mathrm{HBe}$ 抗原陽性の B 型慢性肝炎と 診断され外来通院していた。トランスアミナーゼの軽 度の動摇および $\mathrm{HBe}$ 抗原の出現と消失をくり返してい た。 1991年12月13日, 当院にインターフェロン前の肝
組織評価のため入院となり，1991年12月16日に腹腔鏡 下肝生検を施行した。

入院時身体所見: 身長 $162 \mathrm{~cm}$, 体重 $68 \mathrm{~kg}$. 血圧 $128 / 80 \mathrm{mmHg}$, 脈拍 $74 /$ 分・整. 眼瞼結膜に貧血はな く, 眼球結膜に黄染はみとめられなかった。胸部では 心・呼吸音に異常をみとめず, 腹部では肝・脾を触知 しなかった。

入院時血液生化学検查(表 1$):$ GOT $49 \mathrm{IU} / l$, GPT $66 \mathrm{IU} / l$ とトランスアミナーゼの軽度上昇と, 総タンパ ク質 $6.1 \mathrm{~g} / \mathrm{d} l$, アルブミン $3.5 \mathrm{~g} / \mathrm{d} l$ の低下をみとめるほ か異常をみとめなかった。ICG 停滞率は $13 \%$ で軽度の 遅延を示した。肝炎ウイルス検査では HCV 抗体は陰性 を示したが, HBs 抗原, HBe 抗原, HBc 抗体が陽性

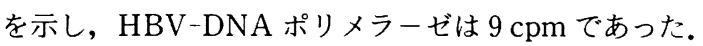

画像検査：腹部超音波検査と腹部 CT 検査では肝に 異常所見をみとめなかった.

腹腔鏡所見 (図 1)：肝左葉では腫大がみられ, 肝辺縁 は比較的鈍で表面は斑点状で凹凸不整が明らかであっ た。肝表面の色調は褐色調で, 白色紋理と赤色紋理が

Intrahepatic ectopic pancreas; A case presenting in the liver tissue of laparoscopic biopsy

Hirotaka Nakazawa, Seiichirou Ogata, Junki Kolke, Yoshio Aida, Shiro Maeyama, Toshiyuki UchiкOSHI $^{1)}$, Akira Sato, Hiroshi SuzUKI ${ }^{2)}$

"The Department of Pathology, St. Marianna University, School of Medicine

${ }^{2}$ Hepato-gastroenterology, Yokohama-shi Seibu Hospital, St. Marianna University, School of Medicine

1)聖マリアンナ医科大学病理学教室

2)聖マリアンナ医科大学横浜市西部病院消化器肝臓内科

$<$ 受付日1999年10月 4 日 $>$ 
表 1 入院時検查成績

\begin{tabular}{lclc}
\hline T.P & $6.1 \mathrm{~g} / \mathrm{d} l$ & WBC & $4400 / \mu l$ \\
Alb & $3.5 \mathrm{~g} / \mathrm{d} l$ & RBC & $467 \times 10^{4} / \mu l$ \\
T.Bil & $0.8 \mathrm{mg} / \mathrm{d} l$ & Plt & $12.9 \times 10^{4} / \mu l$ \\
GOT & $49 \mathrm{IU} / \mathrm{d} l$ & PT & $11.8(10.6)$ 秒 \\
GPT & $66 \mathrm{IU} / \mathrm{d} l$ & HPT & $61 \%$ \\
$\mathrm{LDH}$ & $379 \mathrm{IU} / \mathrm{d} l$ & HBsAg & $(+)$ \\
ALP & $115 \mathrm{IU} / \mathrm{d} l$ & HBsAb & $(-)$ \\
$\boldsymbol{\gamma}-\mathrm{GTP}$ & $29 \mathrm{IU} / \mathrm{d} l$ & HBeAg & $(+)$ \\
$\mathrm{ChE}$ & $7.0 \mathrm{IU} / l$ & HBeAb & $(-)$ \\
$\mathrm{T} . \mathrm{Chol}$ & $200 \mathrm{mg} / \mathrm{d} l$ & HBcAb & $(+)$ \\
TTT & $4.0 \mathrm{U}$ & HBV-DNA & $9 \mathrm{CPM}$ \\
ZTT & $11.0 \mathrm{U}$ & HCV-2nd & $(-)$ \\
\hline
\end{tabular}
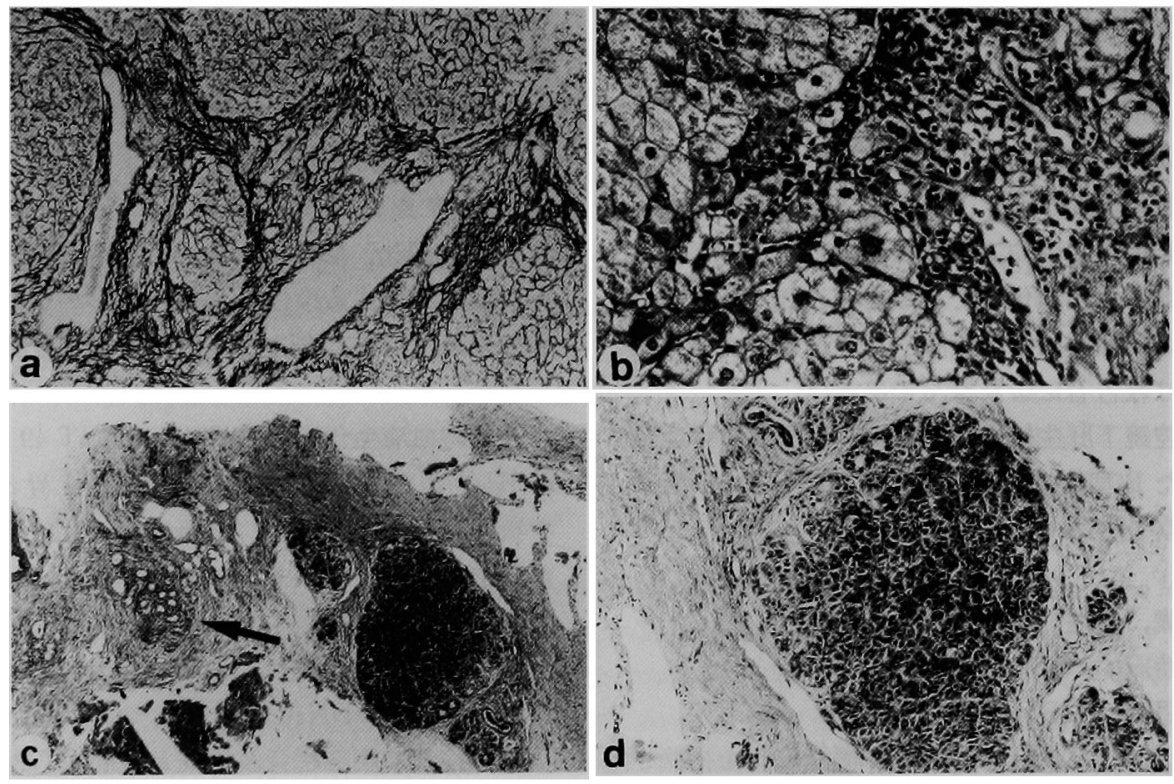

図 2 肝生検組織像：a. 架橋形成性の線維化をみとめ, 一部に小葉改築傾向がみられるが小 葉構造は保たれている。（鍍銀染色 $\times 40 ）$ b. 門脈域には単核球主体の炎症性細胞浸潤をみ とめ, 一部に軽度の piecemeal necrosisをみる（H.E 染色 $\times 400 ） \quad c$. 肝組織の深部側の 一部に肝内胆管付属器腺 (矢印) と腺組織の集簇した小葉をみる。（H.E 染色 $\times 100 ） \quad$ d. 小 葉を構成する細胞は, 一部がエオジン好性の顆粒をもつ腺組織であり, 膵外分泌腺に類似 している.（H.E染色 $\times 200 ）$

目立っていた．肝生検は軽度に萎縮した肝右葉より施 行した。腹腔鏡像は，慢性肝炎の像と考元られた。

肝生検組織像: 架橋形成性の線維化をみとめ, 一部 に小葉改築傾向がみられるが小葉構造は保たれており (図 2-a), 門脈域には単核球主体の炎症性細胞浸潤を
みとめ, 一部に軽度の piecemeal necrosis みる(図 2 -b). 肝実質域では肝細胞に軽度の風船様膨化をみと め, 一部にスリガラス様の変化がみられた。巣状壊死 を伴う実質炎を散見し，以上から B 型慢性肝炎(F2/ A1)とした.さらに, 採取された肝組織の深部側の一部 
に腺管と腺組織の集簇した小葉がみられた(図 2-c)。構 成する細胞は，一部がエオジン好性の顆粒をもつ腺組 織であり，膵外分泌腺に類似していた (図 2-d).

臨床経過：ウイルス量は少なくトランスアミナーゼ は100前後の動摇であったが, 年齢が44歳で, 病理組織 像でもB 型慢性肝炎 (F2/A1) で肝硬変の像ではなかっ たことから，INF- $\alpha$ - $2 \mathrm{~b}$ の 600 万単位の連日14日投与を 施行した. その後, 外来通院となるが, 血液生化学像 ではトランスアミラーゼは 100 前後の動摇を示しており, いまだセロコンバージョンせず HBs 抗原, HBe 抗原は 陽性のままである。

\section{考 察}

異所性膵が肝蔵にみられたという報告例は少ないが, Terada ら ${ }^{3}$ は剖検肝 1000 例の検索で41例 (4.1\%)に肝 内異所性膵組織をみとめたと報告しており, 発生頻度 的にはそれほど稀なものではないと考えられる。この 報告では，発生部位は肝内の中等大から大きな門脈域 にみられ，その大きさは直径 $250 \sim 900 \mu \mathrm{m}$ 程度である. その構成する細胞は, 腺房細胞, 淡明細胞, 導管の要 素をもつ細胞の 3 種類であるが, 肝内異所性膵組織は 肝内胆管付属腺に混じて存在するため, 導管を指摘す るのは困難である.さらに, 免疫組織化学染色では, 膵 $\alpha$-アミラーゼ, トリプシンが陽性であると報告して いる．自験例は針生検で偶然採取された微少な検体で あるため, 未染色標本の作製過程に異所性膵組織の部 位は消失し免疫組織化学染色や電子顕微鏡写真による 詳細な検索はできなかった。

異所性膵は発生学的には, 発生期における腹側原基 と背側原基との癒合が不完全な場合に脺の原基のごく 一部が原腸に取り残され迷入し発生するという説 ${ }^{4} や$, 多機能性上皮細胞の化生により発生するという説豆と, そのどちらも起こりうるという報告 ${ }^{6}$ があるが，そのう ちどれが自験例にあてはまるかは断定できない.

異所性膵の組織学的な分類としては, Heinrich の分 類”が一般的である。この分類では，膵組織を構成する 腺房細胞, 導管, ランゲルハンス氏島の 3 つがそろっ たものを Heinrich I 型とし, 腺房細胞, 導管の 2 つが みられるものをII型, 導管のみのみられるものをIII型 としている. Terada ら ${ }^{3)}$ の41例の報告では, すべての 症例に膵腺房様細胞がみられるが, ランゲルハンス氏 島はみられなかったと報告している。つまり，肝にお ける異所性膵ではII 型が最も多い種類と考えられる. 自験例では, 腺房細胞が確認されII型と考えられたが, 針生検組織から連続切片を作製できなかったため, ラ
ンゲルハンス氏島の有無を確認しえず I 型は否定でき なかった。

さらに, 異所性膵の組織が癌化した報告が散見され るが，胃・十二指腸・空腸にそれぞれ数例の報告があ るにすぎない ${ }^{8-12)}$. 肝臓では肝内異所性膵よりインスリ ン分泌細胞癌が発生したという報告 ${ }^{13}$ があるが，その他

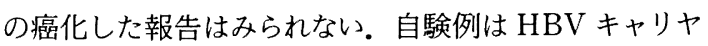
一で活動性のため, 今後は肝細胞癌の発生に注意しな くてはいけないが, 一方で異所性萃組織の癌化の可能 性も念頭に扔き注意深く経過を観察していかなければ ならない症例であると思われた。

腹腔鏡下肝生検にて偶然に肝内異所性膵組織が発見 された B 型慢性肝炎の 1 例を経験したので報告した。

\section{文献}

1）冨岡 勉, 田島義証, 鬼塚伸也, 他：異所性膵. 別冊 日本臨床 領域別症候群 No.10 膵臓症 候群：7-10, 1996

2）杉山政則, 丸山正二, 跡見 裕：異所膵の病態と 診断. 胆と萃 $18: 267-271,1997$

3) Terada T, Nakanuma Y, Kakita A: Pathologic observation of intrahepatic peribiliary glands in 1000 consecutive autopsy livers. Heterotopic pancreas in the liver. Gastroenterology $98: 1333-1337,1990$

4) Barbosa JC, Dockerty MB, Waugh JM : Pancreatic heterotopia: review of the literature and report of 41 authenticated surgical cases, of which 25 were clinically significant. Surg Gynecol Obstet 82:527-542, 1946

5) Clarke B: Myoepithelial hamartoma of the gastrointestinal tract. Arch Pathol $30: 143-$ 152,1940

6) Gray SW, Sandalakis JE: Embryology for surgeons. In: The Embryology for the Treatment of Congenital defects, W B Sunders, Philadelphia, 1972, p263-282

7) Heinrich $\mathrm{H}$ : Ein Beitrag zur histolobie des sogan.akzessorischen Pankreas. virchows Arch [A] 198:392-401, 1909

8）長谷川博康, 土生川光成, 正木裕児, 他：胃迷入 脺から発生した腺癌の 1 例. 日臨外医会誌 55 ： 2899-2902, 1994

9）仙丸直人, 本間浩樹, 橋本正人, 他 : 迷入膵より 発生した十二指腸癌の 1 例. 日臨外医会誌 56 ： 
1171-1174, 1995

10）池田良一, 原田英二, 山本賢資, 他：迷入膵より 発生したと思われる十二指腸癌の 1 例. 胆と膵 $1: 207-212,1980$

11）若原達男, 酒井 勉, 鳥沢英紀, 他: 十二指腸壁 内迷入膵より発生した異所性膵癌の 1 剖検例. 岐 阜市民病年報 $8: 133-140 ， 1988$
12）三枝奈芳紀, 田中寿一, 土屋俊一, 他：異所性膵 組織から発生したと考えられた小腸癌の 1 例. 手 術 49:715-717, 1995

13) Ballinger $\mathrm{J}$ : Hypoglycemia from metastasizing insular carcinoma of aberrant pancreatic tissue in the liver. Arch Pathol $32: 227-285$, 1941 